$\triangle C T A \mathbb{N E O P H I L O L O G I C A}$

UDK: 929Burton R. F.:910.4(497.4)

DOI: 10.4312/an.51.1-2.17-23

\title{
Sir Richard Francis Burton Reconsidered and His Travels to Slovenian Lands
}

\author{
Igor Maver
}

\section{Abstract}

Sir Arnold Wilson delivered a lecture before the Royal Asiatic Society on 27 May 1937 in London at 74 Grosvenor Street as the Fifth Burton Memorial Lecture. Regardless of the fact that Burton was indeed an orientalist and an exponent of the British Empire, he nonetheless often challenged many aspects of the dominant British ethnocentrism of his day and decided to 'go native' and get thus immersed into and possibly become part of the culture of the then Other. In his texts he sometimes openly critized the colonial policies and practices of the British Empire, which can be seen also in the selection of Burton's extracts of texts presented at the Fifth Memorial Lecture discussed here. The article also brings the descriptions of his travels to Lipica on Slovenian ground within the Austro-Hungarian empire.

Keywords: Richard F. Burton, orientalism, travel literature, Slovenian lands 


\section{THE ROYAL ASIATIC SOCIETY LECTURE}

Sir Richard Francis Burton was born in Devon on 19 March 1821. His father was an army officer. Burton accompanied his parents on their frequent trips abroad. Burton was thrown out of Oxford University for disobedience in 1842 and joined the army of the East India Company, where his knowledge of local languages helped his work in surveying and in intelligence. In 1853, taking leave from the company, he undertook a 'Hajj' or pilgrimage to Mecca, in disguise, and his account of this trip made him famous. The following year he explored what is now Somalia with a number of other officers. In 1857, Burton and his fellow officer John Speke embarked on a Royal Geographical Society funded expedition to explore inland from the east African coast, with the hope of finding the source of the Nile. When they arrived at Lake Tanganyika, Speke was almost blind and Burton could hardly walk. Speke travelled on alone and discovered Lake Victoria, which he was convinced was the Nile's source. Burton disagreed and this contributed to a long and bitter quarrel between the two of them. Burton joined the Foreign Office and was appointed consul in Fernando Po, an island off the coast of West Africa. His wife Isabel, whom he had married in 1861, was unable to join him as the climate was considered too unhealthy for her. They were reunited when he was transferred to Brazil and then, in 1869, to Damascus. In 1871, he was moved to Trieste, where his position as a British consul gave him plenty of time to write. Burton was a prolific author, mainly on travel and ethnography. He also translated classical and literature, with a particular interest in eastern erotica: he translated and printed the Kama Sutra (1883) and The Perfumed Garden (1886). He also published a complete edition of the Arabian Nights (1885 - 1888). Burton died in Trieste on 20 October 1890 and is buried in London together with his wife Isabel. A fictionalized version of his travels in Asia and Africa is rendered suggestively by Iliya Troyanov (Troyanov 2009).

The Royal Asiatic Society was established, according to its Royal Charter of 11 August 1824, to further "the investigation of subjects connected with and for the encouragement of science, literature and the arts in relation to Asia«. Due to the nature of the Society's close link with the British Empire in the East, much of the work of the society has been focused on topics concerning the Indian subcontinent. However, the target countries of the Society extend far beyond India: they include all of Asia, Islamic North Africa, and Ethiopia, which coincided with Burton's interests. The Society, even today, does not concentrate specifically on recent political history and current affairs, while it does, however, represent Asian cultural studies research with its regularly published Journal.

Sir Arnold begins his lecture, as would be expected, in most complimentary terms, reviewing Burton's status in the late 1930s: 
No Englishman of the nineteenth century lived a more romantic life; the lives of few aroused more acrid controversy. Yet he is little remembered today... Sir Richard Burton was honoured by no university, and, until he turned to translations of oriental erotica, his contributions to literature attracted comparatively little attention outside a small circle. His object was neither fame nor money, buta $\mathrm{n}$ honourable desire to place fully on record all he knew and could discover upon any subject which interested him. His interests were as varied as the countries in which he dwelt, as an official of the Government of India, and, later, as a Consul. Those who followed in his footsteps in Syria, Arabia and Africa, men such as Stanley, Johnston, Du Chaillu, Lorett Cameron, Philby and Thomas, have borne witness to his conscientious adherence to geographical truth.... When he dies, The Times, in an obituary notice, observed that his name was' in popular estimation associated with Africa, and rightly so, for there he did his most valuable and original work.' $\mathrm{He}$ is remembered to-day mainly as an explorer of Arabia. (Wilson 2)

After his famous explorations in the Near East in what is today Saudi Arabia and in search of the source of the Nile he got married and was given the post of a British Consul at Fernando po on the West coast of Africam known as "the Foreign Office grave«. An explorer at heart, he was not encoured to explore. Wilson reports how his application for surveying instruments, made shortly after his arrival at his post, was endorsed at the Foreign Office as follows:

I.

Is there any precedent?

II.

No; I think it objectionable that our Consuls should furnished with such things. He was instructed accordingly! (Wilson 5)

Wilson in continuation expresses something extremely important:

He was no imperialist. 'I confess to holding the British policeman to be, like the beefsteak, a bore, a world-wide nuisance.' (Burton Gelele, qtd. in Wilson 5)

Wilson in his published 1937 lecture continues in the same apologetic vein for Burton, postulating him as a person that saw contemporary British reality as less humane than that in Africa, for example, especially as regards the downright inhuman punishment and prison system, quoting from Burton's Gelele:

At times he would rebuke the manners the manners and customs of this country by comparing them to those of some savage land.

Female criminals are executed by officers of their own sex, within the palace walls, and not in presence of men. Dahomey is therefore in one point more 
civilised than Great Britain, where they still hang even women, and in public, and in 1864 we hung four murderers on the same gibbet before 100,000 gaping souls at Liverpool. (Burton 1864: 21; 277)

and reminds us that negroes did not, at their worst, invent the hideous punishments of eighteenth-century Europe nor, as in England, hang boys and girls and men and women for trifling offences.

'What white men have done, white men must undo,' he exclaims.

Nations are poor judges of one another: each looks upon itself as an exemplar to the world, and vents its philanthropy by forcing its infallible systems upon its neighbour....The Anglo-Saxon has much to do at home before he sets out to regenerate mankind.

We imprison, punish, and compel to labour our beggars and vagabonds, if they fail to prove how they subsist. We flog youths who are to the full as intellectual as the child-man negro. (Burton 1864: 328)

Sir Arnold Wilson in his published lecture, which has just over twenty pages, clearly cannot avoid Burton's famous translation (Orientalist as it were) of the Arabian Nights into English, which came out in 1885-8 with The Burton Club for Private Subscribers in ten volumes, entitled by Burton as The Book of The Thousand Nights and a Night. With Introduction Explanatory Notes on the Manners and Customs of Moslem Men and a Terminal Essay upon the History of the Nights. It was probably his greatest commercial and financial success on which he worked while stationed in Trieste as the British Consul, who only received very meagre salary.

It gave him a chance of placing on record what he knew upon many subjects and it brought in money which was an absolute necessity. The demand for it surprised him. The technical excellence of his translation is undisputed: to the value to scholars and psychiatrists of his learned notes all workers in this field have testified. He described it as a work of scholarship published in order that the rulers of the East should understand the mainsprings of eastern life.... (Wilson 21)

Wilson, moreover, touches upon Burton's »sensuality« in this regard but pronounces him not immoral. The mention of his wife Lady Isabel is somewhat naive here, since he defends her right to have burned Burton's notes and letters in the backyard of their Trieste villa, Villa Gosleth/later called Economo after his death, which may have »damaged his reputation«.

No man could ever have written it who was not, like thousands in every age and in every country, profoundly interested in, and attracted by, sensual experiences. Burton was unique only because he was also a scholar devoid of mauvaise 
bonte, an Orientalist and a linguist. He has done no harm to our morals. That he knew what true love means may fairly be deduced from the passionate devotion to him of his wife, a devout Roman Catholic, who shared his trials and his disappointments and did what she could to ensure that his achievements should not be forgotten. We may regret, but we must condone, the destruction of notes and journals which, in other hands, might, if published, have damaged his reputation. (Wilson 21)

The final description of Burton's death and funeral in Trieste shows just how well-known and well-liked he was, an Englishman, in his adopted city, almost as an Italian, as an Austrian. He received the greates posthumous honours in a military funeral, although later on his body was tarnsported to England where he is buried at Morlake in a tomb built as an Arab desert tent.

On his death in trieste on October 20,1890, the Roman Catholic Bishop of Trieste conceded to him the greatest of all funeral ceremonies of the Roman Catholic Church, and the authorities a gorgeous military funeral, such as was only accorded to royalty-an honour never befor accorded in Austria to a foreigner...., and of the 150,000 persons who formed the population of Trieste few who could walk did not witness it. The Diet of Trieste heard an oration in his honour and three great funeral requiems were sung, with Mass and all the obsequies. (Wilson 22)

\section{THE BURTONS IN TRIESTE AND SLOVENIAN LANDS}

Trieste has been associated with two well-known English-speaking names of people who resided in it for a number of years, James Joyce and Sir Richard Francis Burton who lived there during 1872-1890. Trieste was until the First World War the main port of the Austro-Hungarian empire with a mixed population of Italians, Slovenes, but also Austrians, Greeks, Jews and many other nationalities. Just as the Burtons went for a long cure in the famous resort of Opatija (then called Abbazia), which Sir Richard described so vividly, so did they often like to visit the location and little hamlet of Lipizza (today's Lipica spelt in the Slovenian language, which means a small lime-tree, since there are many such trees in the meadows there still today), nowadays in the state of Slovenia close to the Italian border. It has been famous for its musical, dashing white Lipizzaner horses that made they way also to the Habsburg court in Vienna. It is situated on the Karst plateau just above Trieste and was thus much more pleasant in the stifling hot summer months than Trieste situated by the sea below. As can be seen from his letters and postcards the Burtons for this reason also liked to spend longer summer periods of time in Opcina (Hotel 
Obelisco), today's Opicina (Opčine in Slovenian), a small town on the Karst rim just above Trieste, which was in the late nineteenth century almost predominantly populated by Slovenian-speaking population. Lady Isabel and Sir R.F. Burton's frequent drives inland (into Istria as they mistakingly called it then) were of short duration, as the following extract testifies to:

One of our favourite drives was to Lipizza, the Emperor's stud. It was established three hundred years ago. It is about two hours from Trieste. You come to a kind of farm, where you may get something to eat. You are then taken to the stables, where the Emperor keeps about nine thoroughbred Arab stallions, and afterwards you are taken through the park, where are herds of thoroughbred mares, chiefly Hungarians and Croats, most of them with foals, perhaps two hundred including foals. If anything is not perfect it is sold, and thus you see a very good breed of horses, in Trieste, often drawing a cart. The pleasantest way to make this trip for your own comfort is to take a luncheon basket for yourself and nosebags with corn for your horses, as well as a small tub or pail to draw water for them, as nothing will induce them - and rightly - to let your horses come anywhere near the stud, or to drink out of anything belonging to their horses, and two hours there and two hours back is a long way for animals to go without drink or any refreshment. (Burton 1893: 30)

\section{BIBLIOGRAPHY}

Burton, Isabel. The Life of Captain Sir Richard F Burton. Vol II. New York: D Appleton \& Company, 1893. I am indebted for this information to Michael Walton.

Burton, Richard F. Mission to Gelele, King of Dahome. Vol I. and II. London: Tinsley Brothers, 1864.

Troyanov, Iliya. The Collector of Worlds. London: Faber \& Faber, 2009.

Wilson, Arnold. Richard Burton. Fifth Burton Memorial Lecture. London: Oxford University Press: Humphrey Milford, 1937. I was asked by Mick Walton, the tireless researcher of Burton and the brilliant organiser of the 2017 meeting in Opatija in Croatia in Villa Antonio, to read and discuss a few extracts from this published lecture on Sir Richard F. Burton by Oxford University Press in 1937 which are published here.

Igor Maver

University of Ljubljana, Slovenia Igor.Maver@ff.uni-lj.si

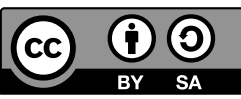




\section{Ponovno vrednotenje sira Richarda Francisa Burtona in njegova potovanja v slovenske dežele}

Sir Arnold Wilson je imel javno predavanje pred Kraljevo azijsko družbo 27. maja 1937 v Londonu kot Peto Burtonovo spominsko predavanje. Ne glede na to, da je bil Burton orientalist in predstavnik britanskega imperija, je vendarle $\mathrm{v}$ mnogočem razbijal tedanji britanski etnocentrizem ter se v smislu mimikrije odločil 'postati domorodec' in tako morebiti postati del kulture takratnega azijskega in afriškega Drugega. Članek prinaša tudi opise njegovega bivanja $v$ Lipici na slovenskih tleh.

Ključne besede: Richard F. Burton, orientalizem, potovalna književnost, slovenske dežele

The author acknowledges the financial support from the Slovenian Research Agency (research core funding No. P6-0265). 